\title{
REX Gene
}

National Cancer Institute

\section{Source}

National Cancer Institute. REX Gene. NCI Thesaurus. Code C17361.

The genes coding for the Regulator X (rex) protein of HTLV-I and II. The Rex phosphoprotein binds to a cis-acting Rex response element in the RNA transcript. It is required for the nuclear export of unspliced viral RNA, and therefore essential for packaging of the RNA in virions. 